\title{
Restorasi resin komposit dengan free-hand layering technique
}

\author{
Danica Anastasia ${ }^{1 *}$, Bebbi Arisya Kesumaputri ${ }^{1}$ \\ ${ }^{1}$ Departemen Konservasi Gigi Program Studi Kedokteran Gigi Universitas Sriwijaya \\ *Korespondensi: danica anastasia@yahoo.com \\ DOI: $10.24198 / \mathrm{jkg} . \mathrm{v} 29 \mathrm{i} 3.15936$
}

\section{ABSTRAK}

Pendahuluan: Restorasi gigi pasca perawatan endodontik merupakan bagian integral dari kunci keberhasilan pengobatan. Beberapa faktor dipertimbangkan untuk keberhasilan restorasi gigi pasca endodontik seperti rasio antara mahkota dan akar, dan jaringan mahkota lainnya. Laporan kasus ini bertujuan untuk mengetahui cara restorasi gigi setelah perawatan endodontic menggunakan komposit resin. Laporan Kasus: Laporan kasus ini menjelaskan cara merestorasi langsung gigi pasca endodontik dengan resin komposit. Seorang pasien wanita berusia 21 tahun datang ke RSKGM Provinsi Sumatera Selatan dengan keluhan utama kerusakan besar pada kedua gigi insisivus sentral rahang atas. Kedua gigi tersebut sudah selesai perawatan endodontik. Kedua gigi tersebut didiagnosis sebagai gigi yang telah dirawat endodontik dan rencana perawatan restorasi langsung resin komposit. Restorasi resin komposit free-hand layering technique dapat dilakukan dalam beberapa kunjungan, karena seringkali memerlukan model kerja atau mock-up. Dalam hal estetika, restorasi ini menawarkan banyak keuntungan dibandingkan dengan pilihan pengobatan lain yang mungkin dilakukan Kontrol satu minggu dan satu bulan menunjukkan keadaan umum dari gigi anterior rahang atas dinilai alami dan estetis. Simpulan: Restorasi pasca perawatan endodontik menggunakan resin komposit dengan free-hand layering technique pada gigi insisivus rahang atas dapat memberikan hasil yang memuaskan.

Kata kunci: Restorasi komposit, free-hand layering technique.

\section{Composite resin restoration with free-hand layering technique}

\section{ABSTRACT}

Introduction: Dental restoration post-endodontic treatment is an integral part of the key to successful treatment. Several factors are considered for the success of post-endodontic tooth restorations such as the ratio between crown and root, and other crown tissue. This case report was aimed to determine dental restoration post-endodontic treatment using composite resin. Case Report: This case report explained how to restore post-endodontic teeth with composite resin directly. A 21-years-old female patient came to Dental Hospital (RSKGM) of South Sumatra Province with a major complaint of significant damages to both maxillary central incisors. Both teeth have finished endodontic treatment. Both teeth were diagnosed as endodontically treated teeth and a direct composite resin restoration treatment plan. Free-hand layering technique of composite resin restoration can be performed on several visits because it often requires a working model or mock-up. In terms of aesthetics, this restoration offers many advantages compared to other possible treatment options. One-week and one-month control showed the general state of the maxillary anterior teeth had been fulfilled the natural and aesthetical aspects. Conclusion: Post-endodontic treatment using composite resin with a free-hand layering technique in the maxillary incisors can provided satisfactory results.

Keywords: Composite restoration, free-hand layering technique. 


\section{PENDAHULUAN}

Restorasi gigi pasca perawatan endodontik merupakan bagian integral dan merupakan kunci keberhasilan pengobatan. Gigi yang telah dirawat endodontik akan rapuh karena dentin kehilangan integritas, kelembaban, dan kekerasannya. ${ }^{1}$ Kegagalan restorasi gigi pasca perawatan endodontik sebagian besar karena kontaminasi saliva. Kontaminasi ini disebabkan oleh kebocoran restorasi atau microleakage yang menyediakan jalan mikroorganisme dan produknya masuk ke bagian akar apikal. Selain itu, keretakan restorasi korona atau pecahnya sisa gigi juga dapat menyebabkan gagalnya restorasi akhir gigi pasca endodontik. ${ }^{2,3}$ Restorasi akhir gigi pasca endodontik harus memperhatikan aspek estetika.

Faktor-faktor yang dipertimbangkan untuk keberhasilan restorasi akhir gigi pasca endodontik, yaitu rasio akar dan mahkota adalah 3:2 dan jaringan gigi keras yang tersisa. Gigi yang dirawat secara endodontik biasanya kehilangan sebagian besar jaringan mahkota yang mempengaruhi retensi dan ketahanan pada restorasi akhir gigi. ${ }^{4}$

Gigi yang dirawat endodontik tidak semuanya memerlukan mahkota penuh sebagai restorasi akhir. Sisa jaringan gigi yang masih besar, masih dapat direstorasi langsung dengan resin komposit untuk mendapatkan hasil yang memuaskan. ${ }^{5}$ Gigi yang masih memiliki marginal ridge yang baik, cingulum, dan tepi insisal dapat dilakukan restorasi langsung dengan resin komposit. ${ }^{5}$ Penggunaan resin komposit sebagai restorasi gigi anterior memiliki banyak keuntungan seperti jaringan keras minimum, waktu kerja yang singkat, warna restoratif gigi alami dan biaya yang lebih terjangkau. ${ }^{6}$
Restorasi resin komposit dengan resin komposit free-hand layering technique untuk gigi anterior dilakukan dengan bantuan silicon index. Penggunaan silicon index ini dapat menghasilkan anatomi palatal yang baik dan dapat menjadi panduan dalam merekonstruksi restorasi gigi seperti gigi asli. Restorasi resin komposit pada gigi anterior dengan resin komposit free-hand layering technique sangat dianjurkan untuk menghasilkan gradasi warna dan transparansi yang baik. ${ }^{6}$ Tujuan artikel ini adalah untuk mengetahui bagaimana cara melakukan restorasi pada gigi pasca endodontik dengan resin komposit dengan free-hand layering technique.

\section{LAPORAN KASUS}

Seorang pasien wanita berusia 21 tahun datang ke RSKGM Provinsi Sumatera Selatan dengan keluhan utama kerusakan besar pada gigi insisivus sentral rahang atas sejak 3 tahun yang lalu. Pemeriksaan intraoral menunjukkan bahwa gigi kehilangan sebagian gigi mahkota. Gigi tersebut masih vital dan peka terhadap perkusi (Gambar 1a). Pemeriksaan radiografi menunjukkan bahwa kedua gigi tersebut memiliki karies yang melibatkan setengah bagian mahkota dan ruang pulpa yang masih utuh. Tidak ada kelainan di daerah periapikal (Gambar 1b). Gigi didiagnosis dengan pulpitis ireversibel disertai periodontitis periapikalis kronis. Rencana perawatan adalah perawatan endodontik dengan restorasi akhir resin komposit free-hand layering technique.

Akses preparasi gigi dilakukan dengan panjang kerja 20,5 mm. Kedua saluran akar gigi dipreparasi dengan teknik step back. Master apical

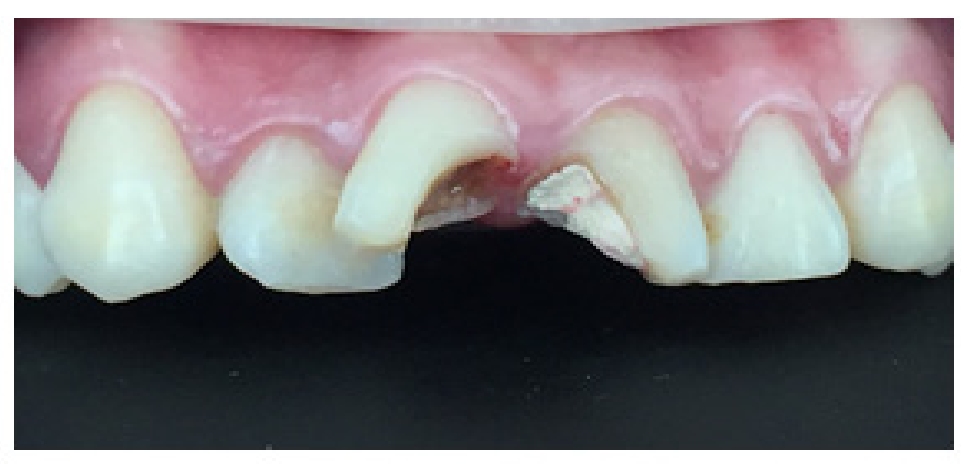

A

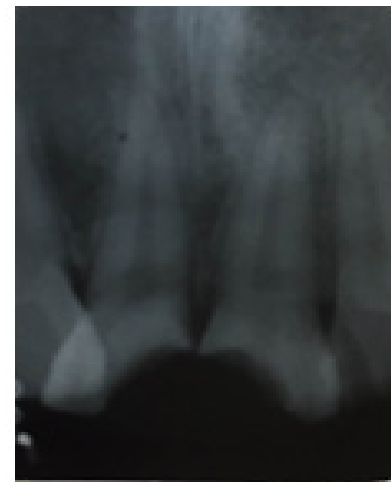

B

Gambar 1. A. Gambaran klinis sebelum perawatan; B. Gambaran radiografi sebelum perawatan 
file (MAF) adalah \#25/20mm. Irigasi dilakukan dengan $\mathrm{NaOCl} 2,5 \%$, saline, dan klorheksidin $2 \%$. Kalsium hidroksida $\left(\mathrm{CaOH}_{2}\right)$ digunakan sebagai medikamen antar kunjungan. Obturasi dilakukan dengan endometason dan gutaperca. GIC tipe 1 (Fuji I, GIC, Jepang) digunakan sebagai seal koronal (Gambar 2).

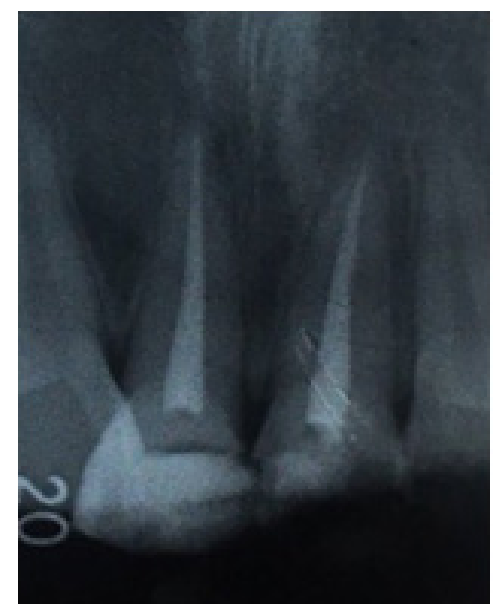

Gambar 2. Obturasi
Model kerja dibuat selama perawatan (Gambar 3a). Mock-up dibuat pada model kerja dengan lilin (Geo wax, Renfert, Hilzingen) (Gambar 3b). Silicone index dibuat dengan putty (ExpressTM XT Putty Soft, 3M ESPE, Jerman) (Gambar 3c).

Gigi diisolasi dengan rubberdam (Optragate, Ivoclar Vivadent, Schaan). Kemudian, pemilihan warna dengan shade guide (Vita, Vitapan Classical, Jerman) dan A3 dipilih (Gambar 4a). Preparasi gigi dilakukan pada bagian labial dan palatal dengan menggunakan fissure diamond bur (Gambar 4b). Self-etching gel (3M ESPE Etchan Gel, Jerman) diaplikasikan pada permukaan mesial sebelum dilakukan restorasi (Gambar 4c).

Permukaan palatal direkonstruksi dengan A2 enamel shade (Filtek Z350 XT, 3M ESPE, Jerman). Kemudian, dilapisi dengan A3 dentine shade (Filtek Z350 XT, 3M ESPE, Jerman) dan A2 enamel shade (Filtek Z350 XT, 3M ESPE, Jerman) sebagai lapisan teratas enamel. Gigi 11 direstorasi dengan prosedur yang sama. Prosedur poles dilakukan dengan Sof-Lex Extra Thin Contouring

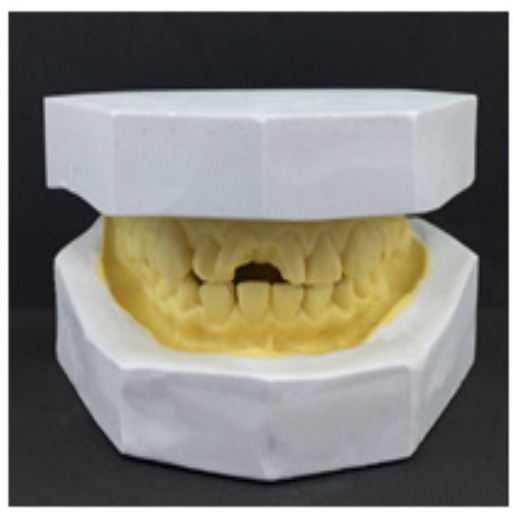

A

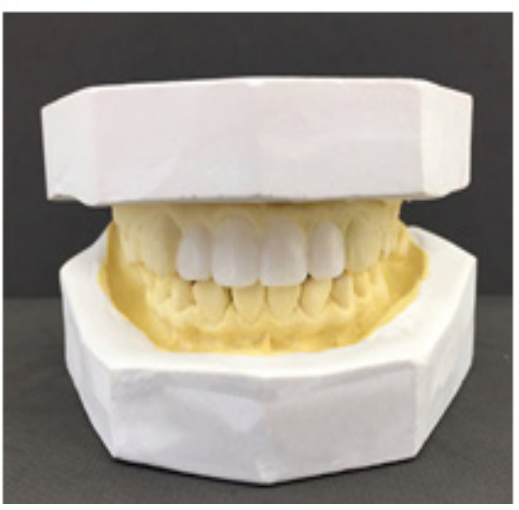

B

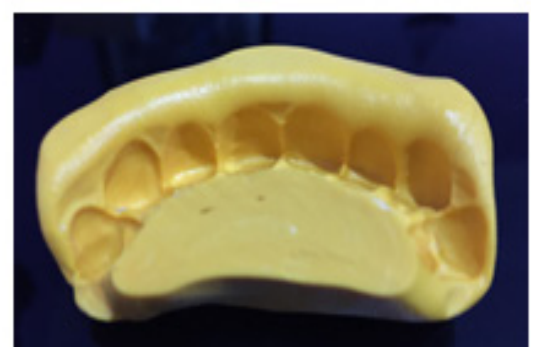

C

Gambar 3. A. Model kerja; B. Mock-up pada model kerja; C. Silicone index

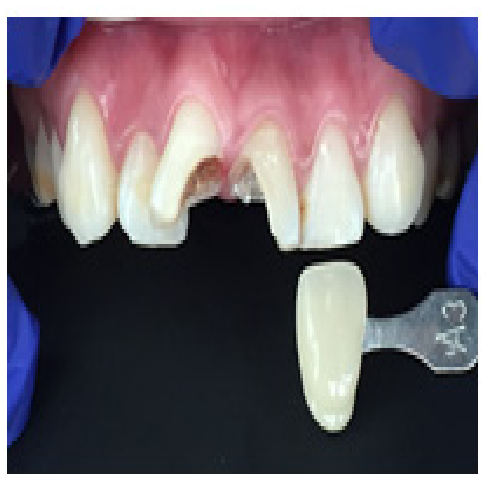

A

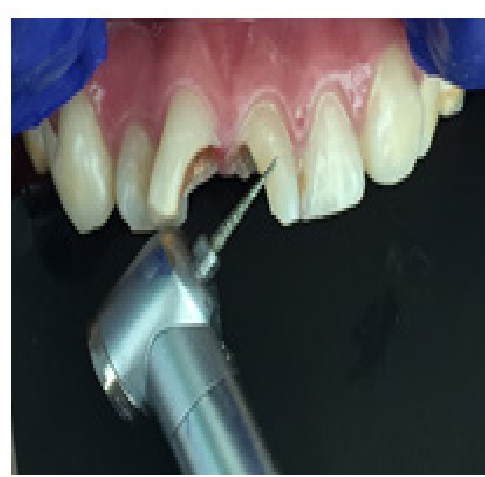

B

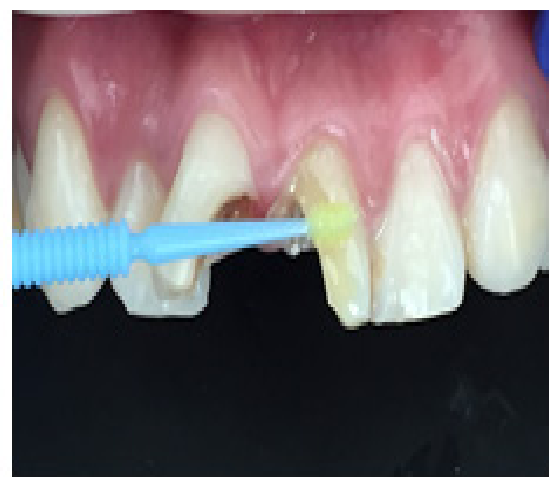

C

Gambar 4. A . Pemilihan warna gigi; B. Preparasi gigi; C. Prosedur etsa 


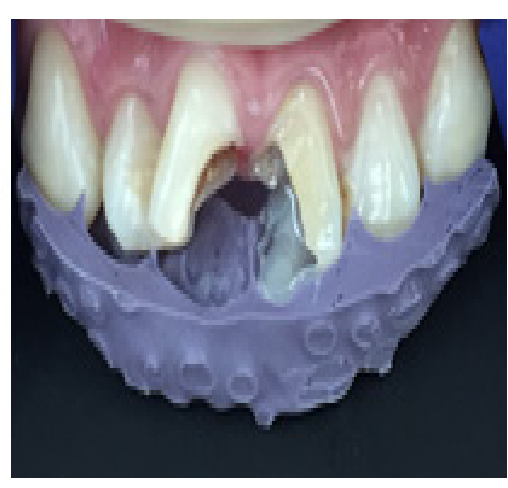

A

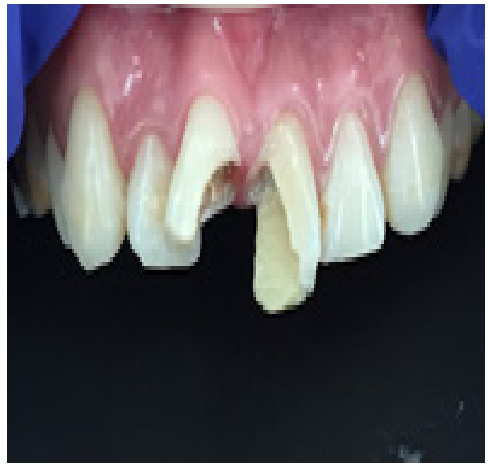

B

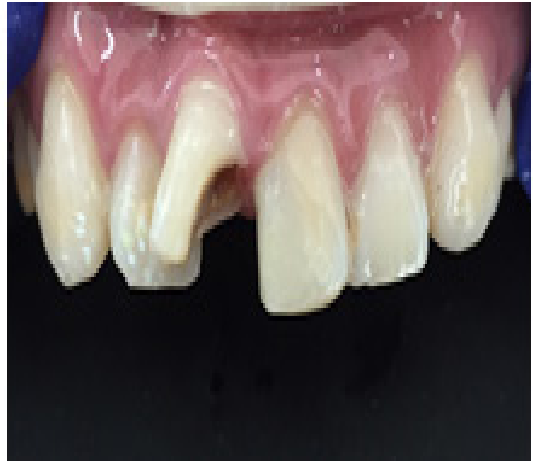

C

Gambar 5. A. Konstruksi bagian palatal; B. Aplikasi lapisan dentin; C. Aplikasi lapisan teratas enamel

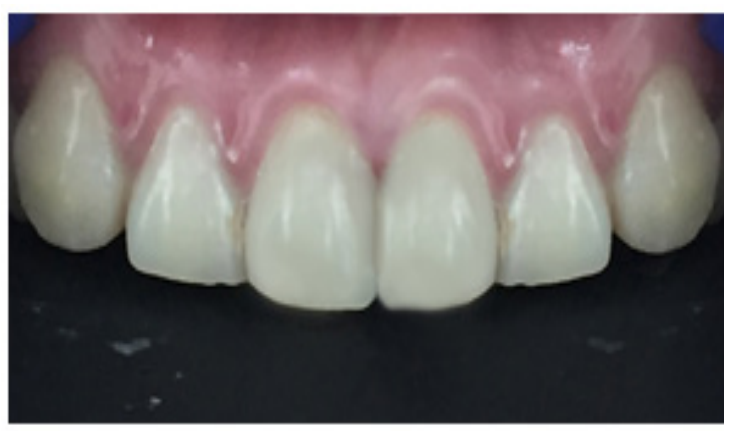

A

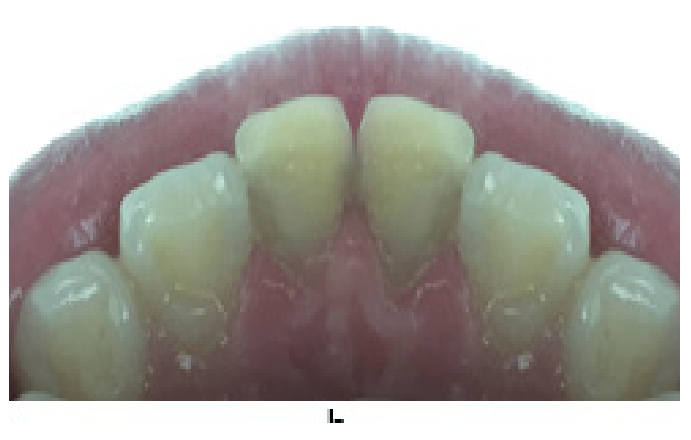

B

Gambar 6. Gambaran restorasi resin komposit pada gigi anterior pasca perawatan endodontik: A. Labial gigi 11 dan 21; B. palatal gigi 11 dan 21

dan Polishing Discs (3M ESPE, USA) (Gambar 5a-c). Pasien diedukasi untuk menjaga kebersihan gigi dan mulut serta diberitahukan jadwal kontrol. Kontrol satu minggu dilakukan untuk memastikan restorasi masih utuh dan estetis. Kontrol satu bulan dilakukan untuk memastikan gigi dan restorasi tidak sensitif, tidak ada perubahan warna, dan tidak fraktur (Gambar 6a-b).

\section{PEMBAHASAN}

Restorasi resin komposit free-hand layering technique dapat dilakukan dalam beberapa kunjungan, karena seringkali memerlukan model kerja atau mock-up. Dalam hal estetika, restorasi ini menawarkan banyak keuntungan dibandingkan dengan pilihan pengobatan lain yang mungkin dilakukan, seperti veneer porselen dan mahkota jaket. Jika terjadi kerusakan, restorasi ini dapat diperbaiki dengan mudah dibandingkan dengan perbaikan restorasi porselen yang mahal dan memakan waktu. ${ }^{7,8}$
Kelemahan restorasi resin komposit freehand layering technique dibandingkan beberapa alternatif restorasi porselen yaitu sebagian besar material komposit memiliki ketahanan fraktur, shear, dan ketahanan tekan yang rendah, serta tidak cocok untuk gigi dengan tekanan kunyah besar yang ditemukan pada situasi klinis tertentu. ${ }^{9}$ Stabilitas warna restorasi langsung resin komposit tidak sama dengan restorasi porselen. Namun, hal ini tergantung pada kualitas prosedur finishing dan polishing dan dapat dicegah pada saat kontrol. ${ }^{10}$ Terlepas dari kenyataan bahwa restorasi resin komposit free-hand layering technique memiliki kekurangan, perkembangan teknik adhesif dan bahan resin berkualitas memberikan kesempatan kepada dokter gigi untuk menciptakan restorasi yang lebih konservatif, fungsional, estetis, ekonomis, dan tahan lama dengan waktu pengerjaan yang singkat. ${ }^{11,12}$

Pemilihan warna gigi merupakan masalah, terutama bila ada kekurangan opasitas pada material warna dentin. Keadaan ini dapat 
menurunkan nilai estetis dari restorasi. ${ }^{13}$ Diagnosis yang tepat dikombinasikan dengan desain dan prosedur restorasi yang baik bertujuan untuk memperbaiki dan mengembalikan penampilan alami gigi. Dengan demikian, pengetahuan tentang morfologi gigi sangat penting, serta aspek mengenai sifat optik dan dinamis dari struktur gigi. ${ }^{14}$

Pembuatan mock-up dalam kasus ini sebelum restorasi akhir merupakan cara untuk mensimulasikan anatomi gigi dan silicon index untuk menjadi panduan restorasi akhir resin komposit. Kontrol satu minggu dan satu bulan menunjukkan keadaan umum dari gigi anterior rahang atas dinilai alami dan estetis. Gambaran klinis kedua restorasi tidak mengalami fraktur dan tidak menunjukkan perubahan warna. Dokter gigi yang berpengalaman dengan pemilihan kasus yang tepat serta teknik dan bahan yang sesuai, dapat melakukan restorasi resin komposit freehand layering technique yang estetis dan tahan lama sehingga dapat memuaskan pasien.

\section{SIMPULAN}

Restorasi pasca perawatan endodontik menggunakan resin komposit free-hand layering technique pada gigi insisivus rahang atas dapat memberikan hasil yang memuaskan.

\section{DAFTAR PUSTAKA}

1. Deliperi S, Bardwell DN. Two year clinical evaluation of non vital tooth whitening and resin composite restoration. J Esthet Restor 2005;17(6):369-79.

2. Slutzky I, Slutzky H, Gorfil C, Smidt. A restoration of endodontically treated teeth review and treatment recommendations: review article. Int J Dent 2009;3(4):145-55.

3. Heling C, Gorfil H, Slutzky K, Kopolovic M, Zalkind I, Slutzky-Goldberg. Endodontic failure caused by inadequate restorative procedures: review and treatment recommendations. J Prosthet Dent 2002;87(6):674-8.
4. Tarigan R. Perawatan pulpa gigi (endodonti). $2^{\text {nd }}$ ed Jakarta: Penerbit Buku Kedokteran EGC; 2006. h. 195-9.

5. Besse TA, Juni JN. Restorasi pada gigi anterior setelah perawatan endodontic. Dentofasial 2012;11(3):187-91.

6. Rina P, Munyati U. Penutupan diastema dengan menggunakan komposit nanofiller. Ind $\mathrm{J}$ of Dent 2008;15(3):239-46.

7. Magne, Belser UC. Porcelain versus composite inlays/onlays: the effects of mechanical loads on stress distribution, adhesion, and crown fexure. Int J Periodon Restorat Dent 2003;23(6):543-55.

8. Ritter AV. Direct resin-based composites: current recommendations for optimal clinical results. Compend Contin Educ Dent. 2005;26:481-82,484-90.

9. Stappert CFJ, Ozden U, Gerds T, Strub JR. Longevity and failure load of ceramic veneers with different preparation designs after exposure to masticatory simulation. J Prosthet Dent 2005;94(2):132-9.

10. Correia AMO, Vieira VM, Rocha DM, Mendonça AAM. Aesthetic restoration of maxillary incisors with composites: case report. Austin J Dent 2015;2(1):10

11. Azzaldeen A, Muhamad AH. Diastema closure with direct composite: architectural gingival contouring. J Adv Med and Dent Scie Res 2015;3(1):134-9.

12. Demirci M, Tuncer S, Ozta SE, Tekce N, Uysal O. A 4-year clinical evaluation of direct composite build-ups for space closure after orthodontic treatment. J Clinical Oral Invest 2015;19(9):2187-99.

13. Ikeda T, Sidhu SK, Omata Y, Fujita M, Sano $\mathrm{H}$. Colour and translucency of opaque-shades and body-shades of resin composites. Eur $\mathrm{J}$ Oral Sci 2005;113:170-3.

14. Wolfart S, Quaas AC, Freitag S, Kropp P, Gerber WD, Kern M. Subjective and objective perception of upper incisors. J Oral Rehabil 2006;33:489-95. 